\title{
POTENSI PASAR PULAI (Alstonia scholaris) SEBAGAI SUMBER \\ BAHAN BAKU INDUSTRI OBAT HERBAL : STUDI KASUS JAWA BARAT DAN JAWA TENGAH \\ (Market Potential of Pulai (Alstonia scholaris) as a Source of Raw Materials of Herbal Medicine Industry : Case Study of West Java and Central Java)
}

\author{
Oleh/By : \\ Indartik \\ Peneliti pada Pusat Penelitian Sosial Ekonomi dan Kebijakan Kehutanan \\ Jl. Gunung Batu No. 5, Bogor \\ Telp: (0251) 8633944, Fax: (0251) 8634924, email : indartik32@yahoo.co.id.
}

Naskah diterima : 29 April 2009 / Edit terakhir : 26 Mei 2009

\begin{abstract}
Pulai (Alstonia Scholaris) can be used as raw materials for herbal medicine, especially for antibypertension drugs. So far, the information about Pulai market medicine for medical plant have not been available yet, so we should to know the Pulai market prospects as industrial raw material herbs. The purpose of this study was to know (1 how big the market prospects of Pulai, (2) the factors affecting the demand for antibypertensive drugs. The research conducted in the Province of West Java, with the assumption thatpeople with hypertension are usually concentrated in urban areas, and Central Java as the herbal industry. The methods of data analysis used in this research are descriptive analysis, analysis of marketing channels and marketing margins, and regression analysi. The results showed that Pulai (Alstonia Scolaris) has a market prospects high enough for the raw materials of herbal medicine from the availability of Pulai raw materials. In Central Java, Pulai have been scattered in conservation area (Jepara, Banjarnegara, and Cilacap). Moreover, Pulai have been developed in Wonogiri and Purworejo. In West Java, Pulai spread in Gunung Halimun and Ujung Kulon National Park, Gunung Jagat Sanctuary (Sumedang), Majalengka, Garut and Bogor. Pulai also have been developed by Perbutani KPH Bogor. Pulai's bark. (Alstonia Cortex) has benefits for treating various diseases, including: anti-diabetic, anti-diarrhea and anti-hypertension. In terms of marketing, Pulai's bark, marketing involves 7 market institutions from producers to end consumers with a 3 chain trade system. Demands of antihypertensive drugs in this study are divided into 2: antihypertensive demand from chemical raw materials and herbal raw materials. Factor affecting demand for antihypertension drugs made of chemical is prices, but the main factors that determine the type of medication to patients are doctors. Whereas for medicinal use Pulai raw materials, market demand began to decline. This is related to changes in consumer tastes from traditional products to modern products (in the form of pills or capsules, notpowder).
\end{abstract}

Keywords: Pulai, hypertension drugs, marketprospects, demand analysis

\section{ABSTRAK}

Pulai (Alstonia scholaris) dapat dimanfaatkan sebagai bahan baku obat herbal, terutama untuk anti hipertensi. Informasi pasar pulai sebagai bahan baku obat herbal belum tersedia, sehingga diperlukan kajian ini. Tujuan penelitian adalah mengetahui (1) prospek pasar pulai sebagai obat hipertensi, dan (2) faktor yang mempengaruhi permintaanya. Penelitian dilakukan di Propinsi Jawa Barat, dengan asumsi penderita hipertensi terpusat di perkotaan, dan Jawa Tengah sebagai daerah industri herbal. Metode analisis data yang digunakan dalam penelitian ini adalah analisis deskriptif, analisis saluran pemasaran dan margin pemasaran serta analisis regresi. Hasil penelitian menunjukkan bahwa pulai memiliki prospek pasar yang tinggi untuk bahan baku obat herbal dilihat dari ketersediaan bahan baku pulai. Di Jawa Tengah pulai tersebar di kawasan konservasi di Jepara, Banjarnegara, dan 
Cilacap, serta dikembangkan di Wonogiri dan Purworejo. Untuk Jawa Barat, pulai tersebar di TN Gunung Halimun, Ujung Kulon, CA Gunung Jagat (Sumedang), Majalengka, Garut dan Bogor serta propinsi Banten. Pulai juga sudah dibudidayakan oleh Perhutani KPH Bogor. Kulit kayu pulai memiliki manfaat untuk mengobati beragam penyakit, diantaranya : anti diabetes, anti diare, dan anti hipertensi. Dari segi pemasaran, kulit kayu pulai melibatkan 7 (tujuh) lembaga pemasaran mulai dari produsen sampai konsumen akhir dengan 3 (tiga) rantai tata niaga. Permintaan obat anti hipertensi dalam penelitian ini dibedakan menjadi 2 (dua), yaitu : permintaan anti hipertensi dari bahan baku kimiawi dan bahan baku herbal. Faktor-faktor yang mempengaruhi permintaan obat anti hipertensi dari bahan baku kimiawi adalah harga, tetapi faktor utama yang menentukan jenis obat untuk pasien adalah dokter. Sedangkan untuk jamu yang menggunakan bahan baku, permintaan pasar mulai berkurang. Hal tersebut berkaitan dengan perubahan selera konsumen dari produk tradisional menjadi produk modern (dalam bentuk pil atau kapsul, bukan serbuk).

Kata kunci: Pulai, obat hipertensi, prospek pasar, analisis permintaan

\section{PENDAHULUAN}

Hasil hutan kayu telah memberikan kontribusi besar terhadap devisa negara pada beberapa dekade yang lalu. Hasil hutan non kayu (HHBK) terbukti lebih bernilai daripada kayu dalam jangka panjang (Wollenberg dan Nawir, 1999), karena merupakan komoditas industri, walaupun merupakan hasil sampingan dari sebuah pohon, seperti getah, daun, buah dan kulit. Kulit kayu yang sudah dimanfaatkan antara lain kulit kayu manis (Cinnamomum bumanii), bahan penyamak kulit dari kulit bakau (Bruguieria sp.) dan kulit pulai (Alstonia spp.) (Pertjunda dan Sumardjani, 2001)

Pulai merupakan salah satu jenis pohon yang tersebar di seluruh Indonesia. Bagianbagian dari pohon ini dapat digunakan mulai getah hingga kayunya. Kulit batang, daun dan bunga dapat dimanfaatkan sebagai obat-obatan. Kayunya dapat dimanfaatkan untuk bahan baku barang kerajinan, pensil, papan tulis, lemari, dan lain-lain (Pratiwi, 2000). Kulitnya telah lama dikenal sebagai obat tradisional untuk anti hipertensi. Menurut Dalimartha (2001), kulit kayu pulai berfungsi sebagai bahan baku obat-obatan, antara lain sebagai peluruh dahak, peluruh haid, stomakik, antipiretik, pereda kejang, menurunkan gula darah (hipoglikemik), tonik dan antiseptik.

Prospek pengembangan pulai sebagai bahan baku obat herbal sangat cerah ditinjau dari berbagai faktor penyokong, diantaranya pulai tumbuh tersebar di seluruh Nusantara, sehingga pasokan pulai bisa diantisipasi, isu global "back to nature" sehingga meningkatkan pasar produk herbal termasuk Indonesia, krisis moneter menyebabkan pengobatan tradisional menjadi pilihan utama bagi sebagian besar masyarakat. Sampai sejauh ini informasi tentang pasar pulai sebagai bahan baku obat herbal belum tersedia, sehingga diperlukan kajian mengenai prospek pasar pulai sebagai bahan baku industri herbal, terutama untuk obat anti hipertensi.

Tulisan ini bertujuan untuk (1) mengetahui seberapa besar prospek pasar pulai sebagai obat anti hipertensi, dan (2) mengetahui faktor-faktor yang mempengaruhi permintaan obat anti hipertensi.

\section{METODOLOGI}




\section{A. Kerangka Pemikiran}

Kerangka analisis prospek pasar pulai dapat dilihat pada Gambar 1.

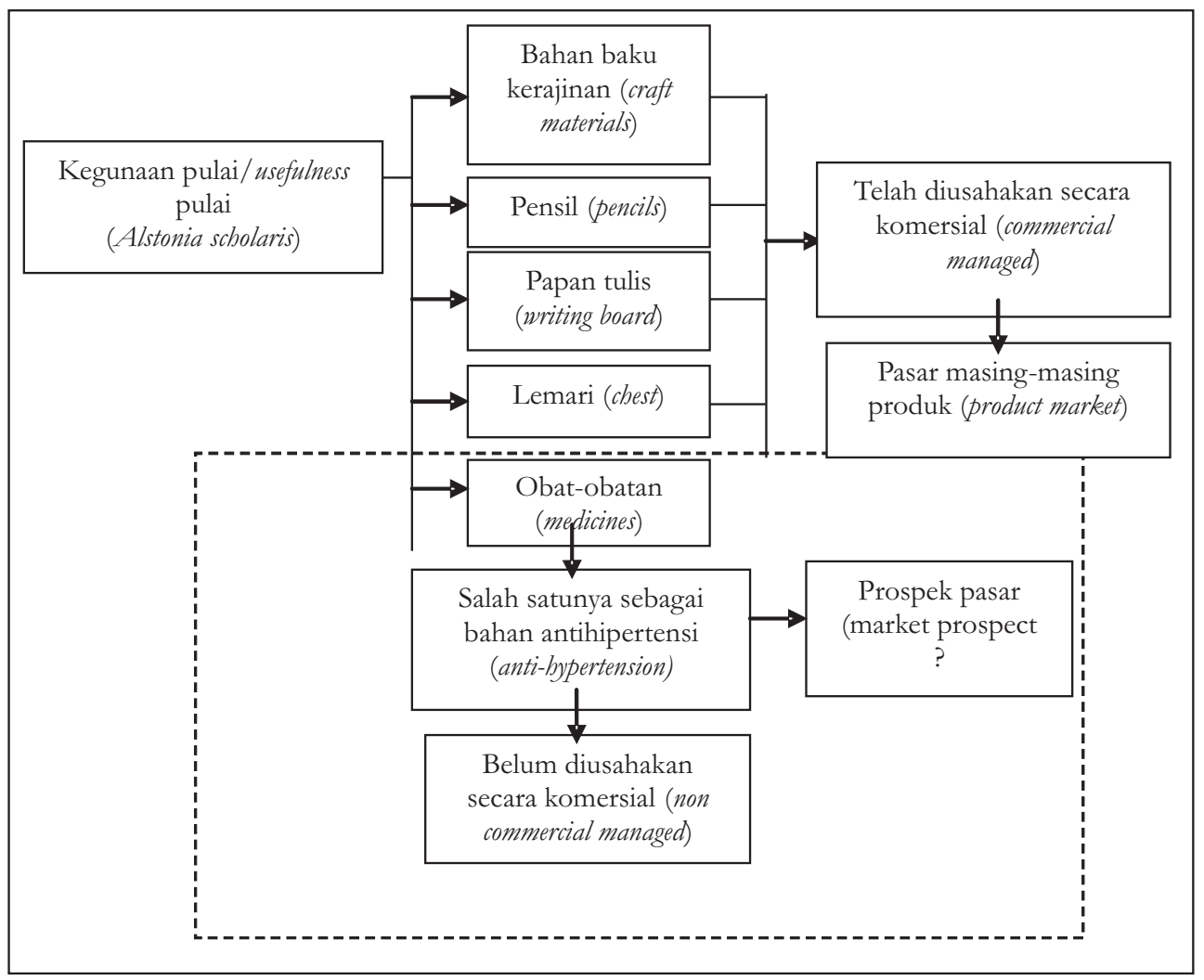

Gambar 1. Kerangka analisis prospek pasar pulai (Alstonia scholaris)

Figure 1. Analytical framework of pulai market prospect

Dari Gambar 1, dapat dijelaskan bahwa kayu pulai (Alstonia scholaris) dapat dimanfaatkan sebagai bahan baku kerajinan, pensil, papan tulis, lemari dan obat-obatan. Pemanfaatan kayu pulai sebagai bahan baku produk turunan sudah diusahakan secara komersial, sehingga sudah memiliki pasar masing-masing. Pemanfaatan bagian pohon pulai dalam dunia kesehatan belum dilakukan secara komersial, walaupun secara tradisional sudah dikenal sebagai antihipertensi. Menurut Dalimartha (2001), kulitnya berkasiat. Pada Penelitian ini lebih difokuskan kepada khasiat sebagai anti hipertensi. Untuk mengetahui prospek pasar sebagai obat herbal yang didekati melalui permintaan anti hipertensi oleh rumah tangga berdasarkan volume penjualan apotek. 


\section{A. Pengumpulan Data}

Pengumpulan data primer dilakukan melalui wawancara dengan para stakeholder yang terlibat dalam perdagangan produk biofarmaka, terutama pulai. Stakeholder yang ditemui adalah : (1) Bidang Pengusahaan Hasil Hutan Dinas Kehutanan Propinsi Jawa Tengah; (2) Perum Perhutani Unit I Jawa Tengah; (3) Balai Konservasi Sumber Daya Alam Jawa Tengah; (4) Badan Pengawas Obat dan makanan (BPOM); (5) PT. Sidomuncul di Unggaran; (6) Balai Penelitian Kehutanan Solo; (7) Perum Perhutani KPH Surakarta; (8) PT. Air Mancur di Solo; (9) PT. Akar Sari di Solo; (10) Bidang Planalogi Dinas Kehutanan Propinsi Jawa Barat; (11) Perum Perhutani Unit II Jawa Barat; (12) Balai Konservasi Sumber Daya Alam Jawa Barat; (13) Perum Perhutani KPH Bandung Selatan; (14) Perum Perhutani KPH Bandung Utara; (15) Perum Perhutani KPH Bogor; (16) PT. Jamu Jago; (17) Apotik Contoh; (18) Pedagang bahan baku jamu.

Permintaan obat hipertensi oleh rumah tangga disini diperoleh dari volume penjualan apotek. Informasi rumah tangga yang membeli tidak diketahui. Data yang dikumpulkan berupa volume penjualan obat hipertensi per bulan tiap ukuran dan merk dagang serta harganya. Data dikumpulkan dari 7 (tujuh) apotek contoh di Propinsi Jawa Barat ${ }^{1}$.

Data peluang pasar pulai sebagai bahan obat hipertensi diperoleh dari industri herbal yang berada di Jawa Tengah. Data sekunder diperoleh dari berbagai dokumen, berupa laporan hasil penelitian, makalah dan prosiding workshop, serta hasil pendataan/inventarisasi.

\section{Pengolahan Data}

Data yang diperoleh dikompilasi dan rekapnya dianalisis. Alat analisis yang digunakan dalam penelitian ini disesuaikan dengan tujuan yang ingin dicapai, sebagai berikut:

1. Untuk mengetahui prospek pasar pulai sebagai obat hipertensi melalui : (1) analisis deskriptif untuk mengetahui pasokan kulit pulai, dan (2) analisis tata niaga melalui identifikasi saluran pemasaran dan margin pemasaran untuk mengetahui ketersediaan pasar kulit kayu pulai sebagai bahan baku obat herbal.

2. Mengetahui faktor-faktor yang mempengaruhi permintaan obat hipertensi melalui analisis regresi linier. Asumsi yang digunakan adalah permintaan obat hipertensi kimiawi merupakan prospek pasar pulai sebagai obat hipertensi, sehingga faktor yang mempengaruhi permintaan obat hipertensi kimiawi juga harus diperhatikan dalam pengembangan pulai sebagai obat hipertensi. Model persamaan regeresi linier adalah sebagai berikut:

$\mathrm{Y}_{\mathrm{ij}}=\mathrm{b}_{0}+\mathrm{b}_{1} \mathrm{X}_{1 \mathrm{ij}}+{ }_{\mathrm{ij}}$

Dimana:

$\mathrm{Y}_{\mathrm{ij}}=$ permintaan obat hipertensi kimiawi oleh rumah tangga per bulan ukuran $\mathrm{i}$ merek dagang j.

$\mathrm{X}_{1 \mathrm{ij}}=$ harga obat hipertensi ukuran i merk dagang $\mathrm{j}$

$\mathrm{b}_{0}=$ intercept

ij $=$ error term

${ }^{1}$ Ukuran contoh sebanyak tujuh apotek tidak menimbulkan masalah dalam menganalisa persamaan regresi linier berganda selama permintaan obat antihipertensi oleh rumah tangga yang dikaji adalah permintaan terhadap individu ukuran dan merk dagang (Astana, 2006). 
Hipotesis : $\mathrm{b}_{1}<0$.

Pengujian dan pendugaan model persamaannya menggunakan perangkat program SPSS.

\section{HASIL DAN PEMBAHASAN}

\section{A. Potensi dan Sebaran Tanaman Pulai}

Pulai (Alstonia scholaris [L.] R. Br.) yang termasuk suku kamboja-kambojaan, tersebar di seluruh Nusantara. Di Pulau Jawa tumbuh di hutan jati, hutan campuran dan hutan kecil di pedesaan, ditemukan dari dataran rendah sampai $900 \mathrm{~m}$ dpl. Kadang-kadang ditanam di pekarangan dekat pagar atau sebagai pohon hias. Tinggi pohon berkisar antara $20-25 \mathrm{~m}$. Batang lurus, diameternya mencapai $60 \mathrm{~cm}$, berkayu, dan percabangan menggarpu. Kulit batang rapuh, rasanya sangat pahit, dan bergetah putih. Daun tunggal, tersusun melingkar 4 9 helai, bertangkai yang panjangnya 7,5 - $15 \mathrm{~mm}$, bentuknya lonjong sampai lanset atau lonjong sampai bulat telur sungsang, permukaan atas licin, permukaan bawah buram, tepi rata, pertulangan menyirip, panjang $10-23 \mathrm{~cm}$, lebar $3-7,5 \mathrm{~cm}$, warna hijau. Perbungaan majemuk tersusun dalam malai yang bergagang panjang, keluar dari ujung tangkai. Bunga wangi berwarna hijau terang sampai putih kekuningan, berambut halus yang rapat. Buah berupa buah bumbung berbentuk pita yang panjangnya $20-50 \mathrm{~cm}$, menggantung. Biji kecil, panjang 1,5 - $2 \mathrm{~cm}$, berambut pada bagian tepinya dan berjambul pada ujungnya. Perbanyakan dengan biji atau setek batang dan cabang. Karakteristik pohon pulai tersebut dapat dilihat di Gambar 2.

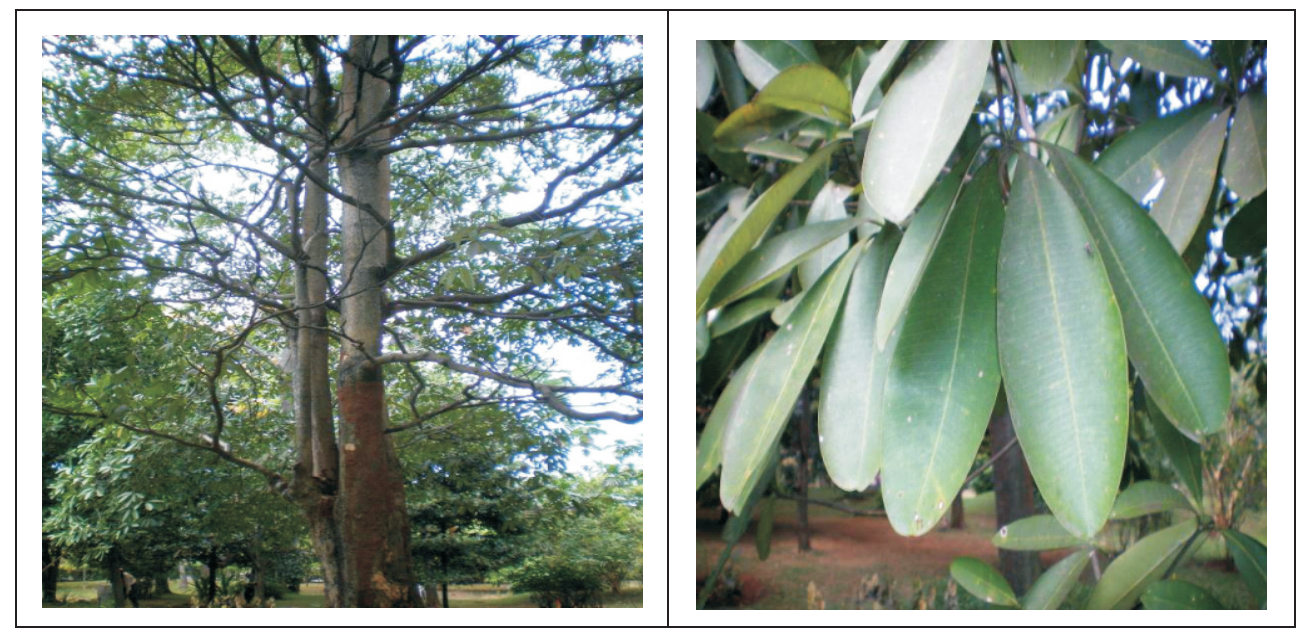

Gambar 2. Pohon pulai (Alstonia Scolaris)

Figure 2. Pulai tree (Alstonia scolaris) 
Nama lokal untuk tanaman ini adalah lame (Sunda), pule (Jawa), polay (Madura). kayu gabus,; pulai (Sumatera).hanjalutung (Kalimantan).kaliti, reareangou,; bariangow, rariangow, wariangow, mariangan, deadeangow; kita (Minahasa), rite (Ambon), tewer (Banda), Aliag (Irian), hange (Ternate) (Indonesia); devil's tree, ditta bark tree (Inggris); chatian, saitan-kajhad, saptaparna (India, Pakistan); Co tin pat, phayasattaban (Thailand);

Pulai ditemukan juga di CA (Cagar Alam) Keling Ia,b,c (Jepara) termasuk dalam seksi konservasi wilayah I, CA Telogo Dringo (Banjarnegara), TWA Gunung Selok (Cilacap), CA Nusakambangan Timur (Cilacap) termasuk dalam seksi konservasi wilayah II. Selain jenis pulai (Alstonia scholaris [L.] R. Br.) juga ditemukan jenis pulai pandak (Rauvolvia serpentina (L.) di SM Gunung Tunggangan (Sragen), yang memiliki kandungan obat yang lebih tinggi (BKSDA Jawa Tengah, 2008).

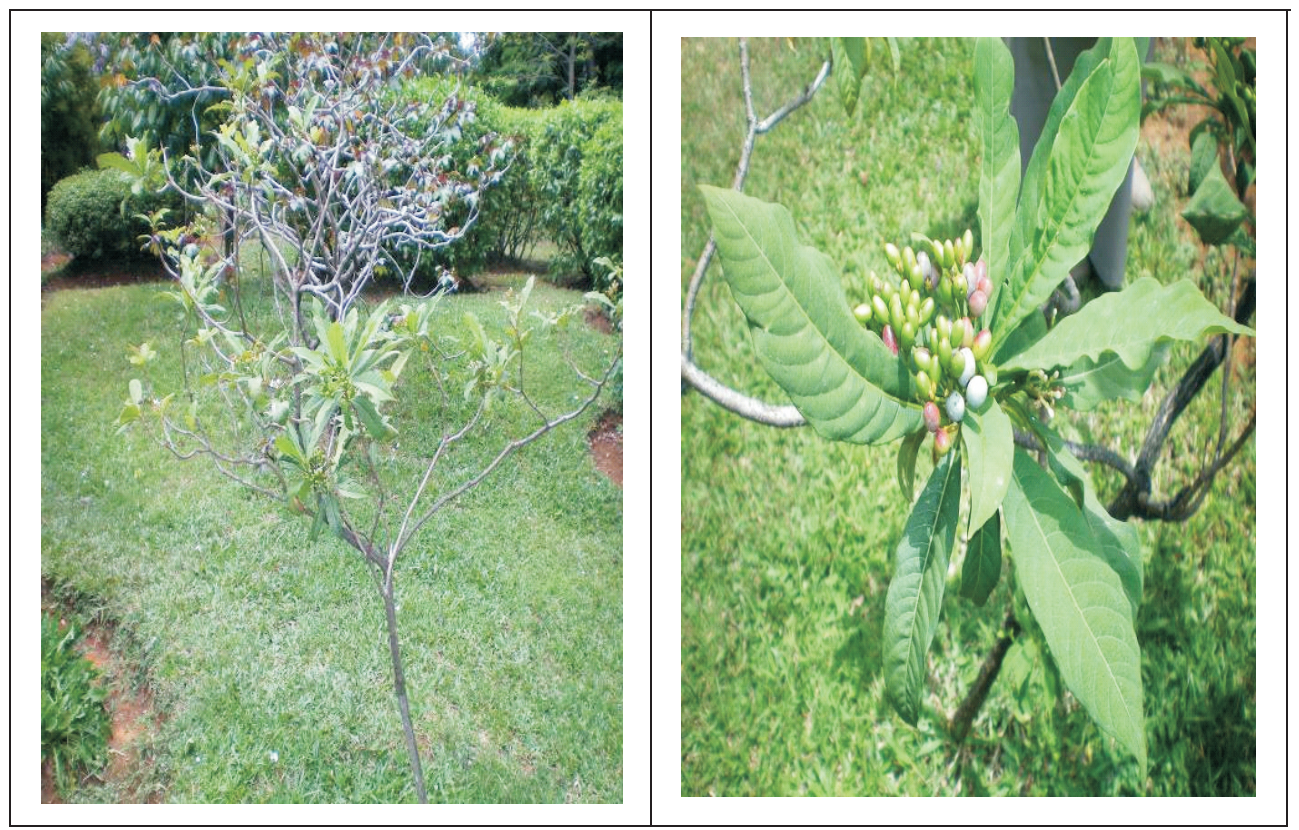

Gambar 3. Pohon pulai pandak (Rauvolvia serpentina (L.)

Figure 3. Pulai pandak tree (Rawvolvia serpentina (L.)

Sedangkan berdasarkan Harini, dkk (2000) tanaman pulai di Jawa Barat terdapat di Taman Nasional Gunung Halimun (TNGH), Taman Nasional Ujung Kulon, Kabupaten Majalengka dan CA Gunung Jagat, Kabupaten Sumedang. Masyarakat Sunda kesepuhan di dalam dan di sekitar TNGH, yaitu di Kecamatan Bayah, Kabupaten Lebak; Kecamatan Cisolok, Kabupaten Sukabumi dan Kecamatan Cigudeg, Kabupaten Bogor melakukan pengobatan tradisional dengan menggunakan jenis tumbuhan sekitar hutan. Pulai atau lame digunakan untuk jamu godokan. Masyarakat sekitar Taman Nasional Ujung Kulon memanfaatkan lame untuk mengobati malaria dan perut kembung. Pule pandak (Ravvolvia serpentina (L.) digunakan untuk mengobati penyakit disentri, radang jantung dan setelah bersalin. Di desa Maja Utara dan Maja Selatan, Kecamatan Maja, Kab. Majalengka kulit lame 
digunakan untuk obat pegal linu, memperlancar pengeluaran darah nifas, kencing nanah, dan malaria. Untuk membersihkan darah nifas seluruh bagian pohon yang digunakan.

Pulai sudah dibudidayakan oleh Perum Perhutani KPH Bogor pada RPH Cirangsad, BKPH Jasinga, Kecamatan Cigudeg, Desa Banyuwangi, Sub DAS Citempuan, DAS Cisadane. RPH Cirangsad memiliki luas 3.338,31 ha, yang terdiri dari hutan produksi sebesar 2.856,01 ha dan hutan produksi terbatas seluas 482,3 ha. Dari hutan produksi tersebut pada petak $30 \mathrm{C}$ yang memiliki luas 99,77 ha ditanami tanaman pulai seluas 6 ha pada tahun 2005 dengan sistem campuran dengan tanaman perhutani. Tanaman ini merupakan hasil kerjasama KOICA (Korea) dengan Litbang Perhutani Cepu. Sedangkan di Petak 30 A, pulai ditanam secara monokultur pada tahun 2004 dengan jarak tanam 3 x 3, sehingga dalam 1 ha terdapat 1110 pohon. Pada petak ini pulai khusus ditanaman oleh Perum Perhutani KPH Bogor dengan luas 6,23 ha (Perhutani, 2009).

Pulai juga dikembangkan untuk tanaman penelitian di kebun percobaan Haurbentes dan kawasan KHDTK (Kawasan Hutan dengan Tujuan Khusus) Wonogiri. Tanaman pulai di kebun percobaan Haurbentes ditanam pada tahun 1991 ( \pm 18 tahun), sebagian dari tanaman tersebut telah berbuah dan tanaman tidak untuk ditebang. Daur pulai adalah 10 tahun karena termasuk tanaman fast growing species. Di KHDTK Wonogiri, tanaman pulai digunakan sebagai tanaman pengisi pada petak $30 \mathrm{~B}$ seluas 1 ha, dengan jumlah tanaman sebanyak \pm 400 pohon dan ditanam pada tahun 2005.

\section{A. Pemanfaatan Tanaman Pulai}

Kulit kayu pulai memiliki rasa pahit, tidak berbau serta memiliki kandungan kimia alkaloida ditain, ekitamin (ditamin), ekitenin, ekitamidin, alstonin, ekiserin, ekitin, ekitein, porfirin, dan triterpen (alfa-amyrin dan lupeol). Daun mengandung pikrinin, sedangkan bunga pulai mengandung asam ursolat dan lupeol. Efek farmakologis triterpenoid dari kulit dapat menurunkan kadar glukosa darah kelinci (Setyarini, 1987). Ekstrak air kulit secara in vivo dapat menekan daya infeksi telur cacing gelang babi (Ascaris suum) pada dosis $130 \mathrm{mg} / \mathrm{ml}$ dan secara invitro menekan perkembang telur berembrio menjadi larva pada dosis $65 \mathrm{mg} / \mathrm{ml}$ (Ranti, 1991). Pemberian infus 10\% kulit dengan dosis 0,7; 1,5 dan 39/kg berat badan kelinci mempunyai efek hipoglikernik (Sulina, 1978).

Sedangkan berdasarkan Daftar Obat Alam (DOA) Edisi II (2008), kulit kayu pulai (Alstonia cortex) digunakan sebagai bahan campuran jamu beberapa penyakit, yaitu seperti dalam Tabel 1. 
Tabel 1. Kulit kayu pulai (Alstonia cortex) sebagai bahan campuran jamu

Table 1. Pulai's bark (Alstonia cortex) as a medicinal compound

\begin{tabular}{|c|l|l|l|}
\hline No. & \multicolumn{1}{|c|}{ Obat penyakit (medicine) } & \multicolumn{1}{|c|}{$\begin{array}{c}\text { Nama produk } \\
\text { (product name) }\end{array}$} & $\begin{array}{c}\text { Nama perusahaan } \\
\text { (company name) }\end{array}$ \\
\hline 1 & Anti diabetes & $\begin{array}{l}\text { Diano } \\
\text { Sari Turas } \\
\text { Diabena }\end{array}$ & $\begin{array}{l}\text { PT. Jamu Jago } \\
\text { PT. Sido Muncul } \\
\text { PT. Jamu Ind. Simona }\end{array}$ \\
\hline 2 & Anti diare & Sakit perut & PT. Jamu Jago \\
\hline 3 & Anti hipertensi & $\begin{array}{l}\text { Atensi } \\
\text { Tensi } \\
\text { Tensina }\end{array}$ & $\begin{array}{l}\text { PT. Jamu Jago } \\
\text { PT. Sidomuncul } \\
\text { PT. Jamu Ind. Simona }\end{array}$ \\
\hline 4 & Anti histamin/mengobati & $\begin{array}{l}\text { Bersih darah } \\
\text { Negatal } \\
\text { Gatal Gudig }\end{array}$ & $\begin{array}{l}\text { PT. Borobudur } \\
\text { PT. Dami Sariwarna } \\
\text { PT. Sidomuncul }\end{array}$ \\
\hline 5 & Antal-gatal & Gadung Klingsir & PT. Jamu Jago \\
\hline 6 & Antitusive/ekspektoransia & Batuk Pilek & PT. Leo Agung Raya \\
\hline 7 & Obat migrain & Sekalor & PT. Leo Agung Raya \\
\hline 8 & Anti wasir & Wasirin & PT. Jamu Ind. Simona \\
\hline 9 & Menstrual disorder & $\begin{array}{l}\text { Haid Sehat } \\
\text { Terlambat Bulan } \\
\text { Terlambat Bulan } \\
\text { Serbuk }\end{array}$ & PT Jamu Jago \\
& & Kolesom & Sehat Wanita \\
\hline 10 & Aprodisiak Pria & $\begin{array}{l}\text { Anton-anton muda } \\
\text { Anton-anton tua } \\
\text { Hamil muda }\end{array}$ & $\begin{array}{l}\text { PT. Jamu Jago } \\
\text { PT. Jamu Jago }\end{array}$ \\
\hline 11 & StaminaWanita & Wanita hamil & PT. Jamu Jago Agung Raya \\
\hline 12 & & PT. Leo Agung Raya \\
\hline
\end{tabular}

\section{Tata Niaga Kulit Kayu Pulai}

\section{Saluran Tata Niaga Kulit Kayu Pulai}

Dari uraian di atas kulit kayu pulai memiliki beragam manfaat untuk obat alam. Sampai sejauh ini belum diketahui kebutuhan industri obat herbal terhadap kayu pulai, bagaimana tata niaganya, besar potensinya dan daerah mana yang selama ini menjadi produsen kayu pulai. Hasil penelusuran dari hilir ke hulu tata niaga kayu pulai sebagai berikut:

\section{a. Industri herbal}

Industri herbal adalah industri yang memproduksi obat jamu herbal. Industri herbal yang berhasil ditemui adalah PT. Sidomuncul, PT. Air Mancur dan PT. Akar Sari, PT. Jamu Jago dan PT. Jamu Simona Indonesia. Dari kelima perusahaan contoh tersebut, empat perusahaan masih memproduksi jamu berbahan baku pulai, dengan volume produksi yang semakin menurun. Mereka biasanya memperoleh bahan baku dari daerah Solo, Wonogiri, Purworejo. 


\section{b. Pedagang Besar/Suplier}

Pedagang besar yang sekaligus suplier adalah pedagang pemasok yang biasanya memperoleh kulit pulai kering dari pedagang pengumpul 2 (Gambar 4) dan menjual ke industri rumah tangga atau penjual jamu godokan atau langsung ke industri jamu. Salah satu pedagang besar terdapat di Kopen, Pasar Gede, Solo Propinsi Jateng. Pedagang besar ini mendapatkan pulai dari pedagang pengumpul di daerah Wonogiri dan Jember untuk Pulai dan Wonogiri untuk pulai pandak.

\section{c. Pedagang Pengumpul 2}

Pedagang pengumpul 2 adalah pedagang pemasok yang biasanya memperoleh kulit pulai kering dari pedagang pengumpul 1 dan menjual ke pedagang pengumpul 3 atau langsung ke industri jamu. Pedagang pengumpul tingkat 2 yang berhasil dihubungi berada di Wonogiri. Biasanya mereka memperoleh bahan baku kulit pulai dari Lampung, Wonogiri, Garut dan Bogor. Pedagang pengumpul ini biasanya menjual kulit pulai kering ke pedagang besar di daerah Solo, Semarang dan Yogyakarta. Selain menjual ke pedagang besar, mereka juga menjual langsung ke pabrik jamu di daerah Semarang dan Wonogiri dengan harga lebih tinggi yaitu Rp. $4000 / \mathrm{kg}$, tetapi dengan pembayaran tempo 0.51 bulan. Volume penjualan per bulan mencapai 2 ton/bulan.

\section{d. Pedagang Pengumpul 1}

Pedagang pengumpul 1 biasanya terdapat di daerah penghasil kulit kayu pulai yang terdapat di daerah Lampung, Wonogiri, Garut dan Bogor. Pada tingkat ini biasanya pedagang memperoleh kulit kayu dari masyarakat pengumpul dalam kondisi kering. Pedagang pengumpul ini biasanya menjual kulit pulai kering ke pedagang pengumpul 2 di daerah Wonogiri.

\section{e. Masyarakat Pengumpul}

Masyarakat pengumpul kulit kayu pulai memperoleh kulit kayu pulai dari tegalan dan hutan. Harga kulit pulai kering bergantung kondisi kulit pulai, jika pengeringan kulit kayu tidak sempurna dan ada noda hitam maka harga turun.

Saluran tata niaga pulai dapat digambarkan seperti dalam Gambar 4.

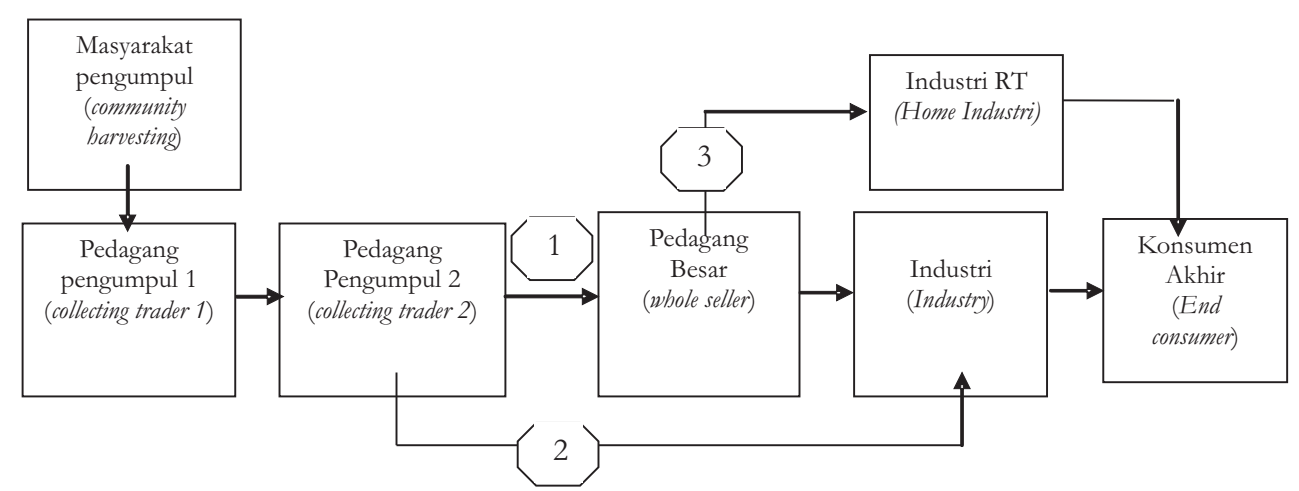

Gambar 4. Saluran tata niga kayu pulai

Figure 4. Marketing channel of pulai bark. 
Dari Gambar 4, terlihat ada tiga saluran tata niaga, yaitu :

1. Masyarakat pengumpul pedagang pengumpul 1 pedagang pengumpul 2 pedagang besar industrikonsumen akhir.

2. Masyarakat pengumpulpedagang pengumpul 1pedagang pengumpul 2 industri konsumen akhir.

3. Masyarakat pengumpulpedagang pengumpul 1pedagang pengumpul2pedagang besarhome industrikonsumen akhir.

\section{Margin Pemasaran}

Analisis margin pemasaran digunakan untuk mengetahui distribusi margin pemasaran yang terdiri dari biaya dan keuntungan dari setiap aktivitas lembaga pemasaran yang berperan aktif, serta untuk mengetahui bagian harga yang diterima setiap pelaku pemasaran (Tomeck, 1990; Sudiyono, 2001). Tujuannya adalah untuk mengetahui efisiensi pemasaran yang diindikasikan oleh besarnya keuntungan yang diterima oleh masing-masing pelaku pemasaran. Semakin tinggi proporsi harga yang diterima produsen, semakin efisien sistem pemasaran. Besarnya keuntungan yang diterima oleh masing-masing pelaku pemasaran relatif terhadap harga yang dibayar konsumen dan atau relatif terhadap biaya pemasaran terkait dengan peran yang diakukan oleh masing masing pelaku. Rincian identifikasi biaya (harga beli) kulit kayu pulai di tingkat lembaga pemasaran atau para pelaku pemasaran dapat dilihat pada Tabel 2 .

Tabel 2. Harga beli kulit pulai kering di setiap tingkat pelaku pemasaran Table 2. The purchaseprice of pulai bark in each market actor

\begin{tabular}{|c|c|c|c|c|c|}
\hline $\begin{array}{c}\text { Kondisi } \\
\text { kulit } \\
\text { (Bark's } \\
\text { condition) }\end{array}$ & $\begin{array}{c}\text { Pedagang } \\
\text { pengumpul 1 } \\
\text { (Collecting } \\
\text { trader 1) }\end{array}$ & $\begin{array}{c}\text { Pedagang } \\
\text { pengumpul 2 } \\
\text { (Collecting } \\
\text { trader 2) }\end{array}$ & $\begin{array}{c}\text { Pedagang } \\
\text { Besar } \\
\text { (whole seller) }\end{array}$ & $\begin{array}{c}\text { Industri } \\
\text { RT } \\
\text { (Home } \\
\text { industry) }\end{array}$ & $\begin{array}{c}\text { Industri } \\
\text { (Industry) }\end{array}$ \\
\hline $\begin{array}{c}\text { Kurang } \\
\text { (less) }\end{array}$ & 700 & 1500 & 2500 & 3000 & - \\
\hline $\begin{array}{c}\text { Bagus } \\
\text { (good) }\end{array}$ & 1000 & 2000 & 3000 & 3500 & 4000 \\
\hline $\begin{array}{c}\text { Rata-rata } \\
\text { (average) }\end{array}$ & 850 & 1750 & 2750 & 3250 & 4000 \\
\hline
\end{tabular}

Sumber : Analisis data primer (Source: Primary data analysis)

Dari Tabel 2 dapat dilihat harga kulit kayu pulai kering berbeda pada setiap tingkat pelaku pemasaran. Karena harga bergantung kepada mutu kulit. Kulit kayu pulai kering berwarna putih tanpa noda hitam biasanya memiliki mutu bagus dan harga lebih tinggi dibandingkan yang bernoda hitam. Pedagang besar menjual kulit kayu pulai kering kepada home industry dan industri, dengan harga lebih tinggi pada industri sebesar Rp. 4000,-, tapi dengan pembayaran tempo 1 bulan. Selanjutnya dengan mengetahui harga jual dan harga beli pada masing-masing pelaku pemasaran maka dapat diketahui besarnya margin pada masingmasing pelaku pemasaran. Secara rinci margin pemasaran dapat dilihat pada Tabel 3. 
Tabel 3. Margin pemasaran kulit kayu pulai

Table 3. Marketing margin of pulai bark

\begin{tabular}{|c|l|l|}
\hline No. & \multicolumn{1}{|c|}{$\begin{array}{c}\text { Pelaku Pasar } \\
\text { (Market actor) }\end{array}$} & \multicolumn{1}{c|}{$\begin{array}{c}\text { Margin pemasaran (Rp/kg) } \\
(\text { Market margin) }\end{array}$} \\
\hline 1 & $\begin{array}{l}\text { Masyarakat } \\
\text { (community harvesting) }\end{array}$ & $\begin{array}{l}\text { Biaya produksi : } \\
\text { Harga jual : Rp. 850,- } \\
\text { Margin pemasaran : }\end{array}$ \\
\hline 2 & $\begin{array}{l}\text { Pedagang pengumpul 1 } \\
\text { (Collecting trader 1) }\end{array}$ & $\begin{array}{l}\text { Harga beli : 850 } \\
\text { Harga jual : 1750 } \\
\text { Margin pemasaran : 900 }\end{array}$ \\
\hline 3 & $\begin{array}{l}\text { Pedagang pengumpul 2 } \\
\text { (Collecting trader 2) }\end{array}$ & $\begin{array}{l}\text { Harga beli : 1750 } \\
\text { Harga jual : 2750 } \\
\text { Margin pemasaran : 1000 }\end{array}$ \\
\hline 4 & $\begin{array}{l}\text { Pedagang pengumpul 3 } \\
\text { (whole seller) }\end{array}$ & $\begin{array}{l}\text { Harga beli : 2750 } \\
\text { Harga jual : 3500 } \\
\text { Margin pemasaran : 750 }\end{array}$ \\
\hline 5 & $\begin{array}{l}\text { Industri } \\
\text { (Industry) }\end{array}$ & $\begin{array}{l}\text { Harga beli : 4000 } \\
\text { Harga jual : } \\
\text { Margin pemasaran : }\end{array}$ \\
\hline
\end{tabular}

Sumber (Source): Analisis data primer (Primary data analysis)

Dari Tabel 3 terlihat bahwa margin pemasaran yang paling besar diterima oleh pedagang pengumpul 2, yaitu sebesar Rp 1.000,-/ kg kulit pulai kering. Margin keuntungan masing-masing pelaku pemasaran belum dapat dilakukan karena sulit mendapatkan data biaya produksi untuk industri atau biaya transportasi pada masing-masing pedagang pengumpul.

Dari ketiga kriteria yang disebutkan diatas (potensi, pemanfaatan dan tata niaga), maka pulai memiliki prospek yang cukup tinggi karena tanaman pulai tersebar di seluruh nusantara, sehingga pasokan kulit kayu pulai dapat terjamin. Selain itu kulit kayu pulai juga memiliki beragam manfaat dan sudah digunakan oleh industri herbal untuk beragam penyakit, termasuk obat anti hipertensi.

\section{Permintaan Terhadap Obat Hipertensi}

\section{Permintaan Obat Hipertensi dari Bahan Baku Kimiawi}

Hipertensi dapat terjadi pada pria maupun wanita. Risiko hipertensi semakin meningkat pada usia 50 keatas. Hipertensi terjadi bila aliran darah menghasilkan tekanan yang sangat besar pada dinding arteri. Hampir $90 \%$ kasus hipertensi tidak diketahui penyebab sebenarnya (Asimtomatis). Gejala mengantuk, mual, muntah dan sakit kepala yang dialami oleh individu dengan hipertensi seringkali disebabkan oleh komplikasi pada organ tubuh akibat hipertensi. Faktor-faktor seperti usia, keturunan (herediter), kebiasaan merokok, konsumsi alkohol, kegemukan, stres, penyakit ginjal, gangguan adrenal, penyakit jantung 
kongenital, obat-obat tertentu, pre-eklamsia, konsumsi garam tinggi, dan gaya hidup kurang aktif dapat mnegakibatkan terjadinya hipertensi (CMPMedica, 2008).

Permintaan obat hipertensi pada penelitian ini digunakan untuk mendekati permintaan terhadap obat herbal untuk anti hipertensi, karena pada awalnya tidak ada informasi bahwa pulai sudah digunakan oleh industri herbal untuk jamu hipertensi. Berdasarkan (CMPMedica, 2008), anti hipertensi digolongkan menjadi antagonis kalsium, antagonis angiotensin II dan anti hipertensi golongan lain (Tabel 2).

Tabel 4. Contoh jenis-jenis obat, nama produk, produsen dan harga obat anti hipertensi Table 4. Examples of the types of drugs, product name, manufacturer and anti bypertension drug prices

\begin{tabular}{|c|c|c|c|c|}
\hline No & $\begin{array}{l}\text { Jenis Obat } \\
\text { (Medicine type) }\end{array}$ & $\begin{array}{l}\text { Nama Produk } \\
\text { (Product name) }\end{array}$ & $\begin{array}{l}\text { Produsen } \\
\text { (Producen) }\end{array}$ & Harga (Price) \\
\hline 1 & $\begin{array}{l}\text { Antagonis } \\
\text { kalsium }\end{array}$ & $\begin{array}{l}\text { - Norvask } \\
\text { - Tensivask }\end{array}$ & $\begin{array}{l}\text { Dexa } \\
\text { Medica }\end{array}$ & $\begin{array}{l}5 \text { mgx30 = Rp. } 173.250,00 \\
10 \text { mgx30=Rp.310.490,00 } \\
5 \text { mg ASKESx30=Rp. } 66.000,00 \\
5 \text { mgx50 =Rp. } 245.000,00 \\
10 \text { mgx50 = Rp. } 440.000,00\end{array}$ \\
\hline 2 & $\begin{array}{l}\text { Antagonis } \\
\text { angiotensin II }\end{array}$ & $\begin{array}{l}\text { - Diovan } \\
\text { - Angioten }\end{array}$ & $\begin{array}{l}\text { Novartis } \\
\text { Indonesia } \\
\text { Kalbe } \\
\text { Farma }\end{array}$ & $\begin{array}{l}40 \text { mgx } 2 \times 14=\text { Rp. } 208.970,00 \\
80 \text { mgx } 2 \times 14=\text { Rp. } 278.670,00 \\
160 \text { mgx2x14=Rp.349.350,00 } \\
50 \text { mgx30=Rp. } 246.000,00\end{array}$ \\
\hline 3 & $\begin{array}{l}\text { Anti } \\
\text { hipertensi } \\
\text { Golongan } \\
\text { Lain }\end{array}$ & $\begin{array}{l}\text { - Cardura } \\
\text { - Ser-Ap-Es }\end{array}$ & $\begin{array}{l}\text { Pfizer } \\
\text { Novartis } \\
\text { Indonesia }\end{array}$ & $\begin{array}{l}1 \mathrm{mgx} 50=\text { Rp. } 305.575,00 \\
2 \mathrm{mgx} 50=\text { Rp. } 522.985,00 \\
5 \mathrm{mg} \times 10=\text { Rp. } 180.101,00 \\
20 \mathrm{mg} \times 10=\text { Rp. } 685.640,00\end{array}$ \\
\hline
\end{tabular}

Dari hasil wawancara dengan responden apoteker, dapat diketahui bahwa yang menentukan jenis obat hipertensi yang dikonsumsi oleh pasien adalah dokter. Sebagai bahan pertimbangan pemberian jenis obat ini adalah penghasilan dari pasien. Jika pasien memiliki penghasilan rendah biasanya direkomendasikan untuk obat generik. Untuk obat nongenerik, penentuan jenis obat dari produsen ditentukan oleh pertimbangan kandungan obat serta promosi dari pihak perusahaan obat. Faktor yang menentukan permintaan obat hipertensi oleh rumah tangga adalah harga obat. Harga obat digunakan untuk mendekati penghasilan rumah tangga karena data penghasilan rumah tangga tidak diperoleh. Promosi tidak bisa dimasukkan sebagai faktor penentu permintaan obat hipertensi karena obat resep dokter tidak boleh diiklankan.Hasil analisis regresi OLS (Ordinary Least Square) dapat dilihat pada Tabel 5 . 
Tabel 5. Hasil analisis regresi OLS permintaan obat anti hipertensi Table 5 . The results of OLS regression analysis of anti bypertension drug demand

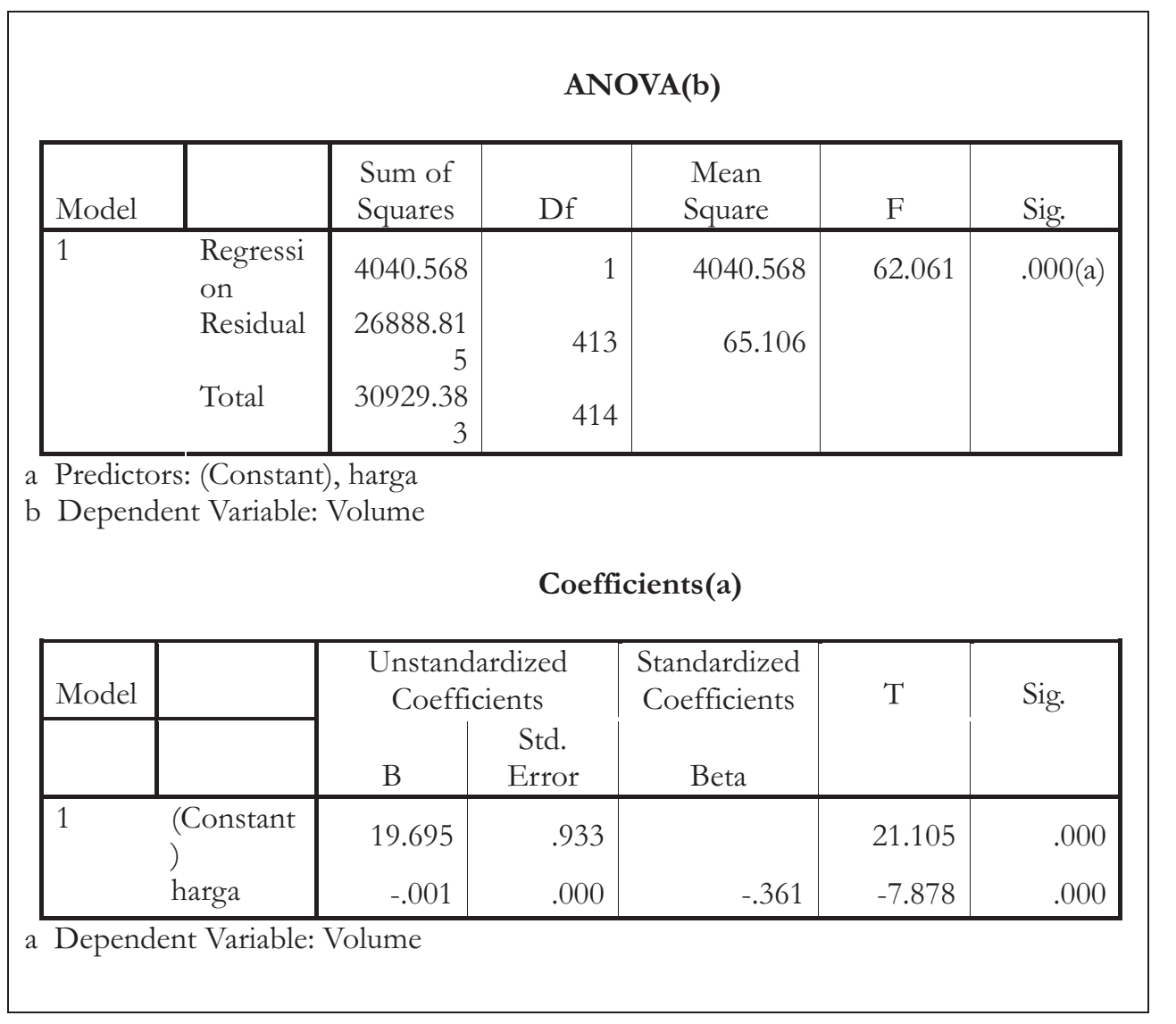

Dari Tabel 5, menunjukkan bahwa harga obat hipertensi berpengaruh nyata terhadap volume permintaan obat hipertensi. Harga berpengaruh negatif terhadap volume permintaan yang artinya semakin mahal harga obat volume permintaan semakin menurun. Ini menunjukkan bahwa harga sangat berpengaruh terhadap permintaan obat, sehingga memberikan peluang obat herbal masuk karena harganya relatif murah.

\section{Permintaan Obat Anti hipertensi dari Bahan Baku Herbal}

Meningkatnya kesadaran masyarakat terhadap kelebihan obat herbal dan harga yang relatif murah dibandingkan obat kimia menjadi suatu peluang pengembangan obat herbal, termasuk obat hipertensi berbahan baku herbal. Dari wawancara dengan responden industri di Semarang dan Solo, kebutuhan industri herbal terhadap kayu pulai tidak terlalu tinggi dan cenderung menurun. Menurut Manajer R \& D PT. Sidomuncul, ada kecenderungan produk yang dihasilkan bersifat promotive atau untuk menjaga stamina, karena produk ini memiliki permintaan pasar yang tinggi dan PT. Sidomuncul akhir-akhir ini memfokuskan pada produk ini. Produk unggulan PT Sidomuncul adalah Tolak Angin, Kuku 
Bima, Jahe Wangi dan Kunyit Asem. Untuk tolak angin, PT.Sidomuncul menggunakan kulit kayu manis (Cinnamomum camora), karena terbatasnya pasokan kayu manis tipe ini, maka di substitusi dengan jenis kayu manis lain (Cinnamomum burmani). Sentra kayu manis adalah di $\mathrm{KPH}$ Banyumas dan hutan rakyat dan hutan negara di Banyumas. Salah satu cara untuk mengatasi kelangkaan kayu manis ini, perusahaan telah mengembangkan teknologi sehingga memungkinkan kayu manis yang diolah merupakan ranting ( $\Phi 2 \mathrm{~cm}$ sampai ujung), sehingga pohon kayu manis tetap lestari. Sebagai gambaran besarnya permintaan terhadap kayu manis, perusahaan ini tiap bulan memerlukan sekitar 20 ton kayu manis kering, dengan harga berkisar antara 1000 1500/kg.

Sedangkan untuk jamu yang menggunakan bahan baku kulit pulai permintaan pasar mulai berkurang, dan jamu berbahan baku kulit pulai yang masih diproduksi adalah Tensi (obat tekananan darah tinggi) dan Sari Turas (obat diabetes). Kebutuhan bahan baku pulai sendiri relatif kecil, yaitu sekitar $20 \mathrm{~kg} / \mathrm{bulan}$, dengan pengiriman langsung sebanyak $200 \mathrm{~kg}$ untuk 10 bulan, dengan harga Rp. 4000/kg (Tabel 6).

Tabel 6. Kebutuhan bahan baku pulai oleh industri, produk dan harga produk.

Table 6. Pulai raw material needs by industry, products andproducts prices

\begin{tabular}{|c|c|c|c|c|c|}
\hline No & $\begin{array}{l}\text { Perusahaan } \\
\text { (company) }\end{array}$ & $\begin{array}{c}\text { Kebutuhan } \\
\text { Pulai } \\
\text { (demand) } \\
\text { (kg/bln) }\end{array}$ & $\begin{array}{l}\text { Produk } \\
\text { (product) }\end{array}$ & $\begin{array}{c}\text { Volume Produksi } \\
\text { (volume production) } \\
\text { bungkus/bln } \\
\text { (sacks/month) }\end{array}$ & $\begin{array}{c}\text { Harga (price) } \\
\text { Rp/bungkus } \\
\text { (Rp/sacks) }\end{array}$ \\
\hline 1 & PT. Sidomuncul & 20 & $\begin{array}{l}\text { Tensi } \\
\text { Sari Turas }\end{array}$ & \begin{tabular}{|l|}
46.879 \\
16.042
\end{tabular} & $\begin{array}{l}373 \\
373\end{array}$ \\
\hline 2 & PT. Akar Sari & $25-50$ & 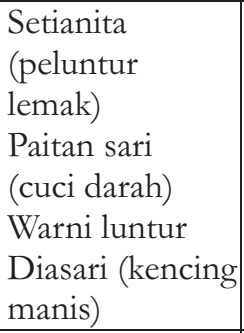 & $\begin{array}{l} \\
- \\
- \\
- \\
-\end{array}$ & $\begin{array}{l}32.500 \\
15.000 \\
15.000 \\
15.000\end{array}$ \\
\hline 3 & PT. Jamu Jago & 200 & $\begin{array}{l}\text { Diano } \\
\text { Atensi } \\
\text { Kolesom } \\
\text { Gadung klingsir } \\
\text { Terlambat bulan } \\
\end{array}$ & $\begin{array}{r}5.000 \\
20.000 \\
15.000 \\
150.000 \\
25.000 \\
\end{array}$ & $\begin{array}{r}1100 \\
1100 \\
1100 \\
750 \\
750 \\
\end{array}$ \\
\hline \multirow[t]{2}{*}{4} & \multirow[t]{2}{*}{ PT. Air Mancur } & - & Sanggageni & 1500 & 400 \\
\hline & & \multicolumn{4}{|c|}{ Pulai diganti dengan seledri } \\
\hline
\end{tabular}

Dari Tabel 6, dapat dilihat bahwa kebutuhan bahan baku pulai relatif kecil apalagi dibandingkan dengan kebutuhan bahan baku kayu manis (hanya sekitar $1 \%$ dari kebutuhan kayu manis). Selama ini PT. Sidomuncul tidak mengalami kesulitan bahan baku kulit pulai, karena kebutuhannya kecil. PT. Sidomuncul mendapatkan pasokan kayu pulai dari suplier yang berasal dari Solo. 
PT. Akar Sari yang berlokasi di Solo, memiliki beberapa jamu yang menggunakan bahan baku pulai, namun karena tidak terdapat dalam buku DOA edisi 2, maka tidak seluruh kompisisi dari jamu yang diproduksi dapat diketahui. Beberapa contoh dari jamu yang dapat dilihat di dua toko jamu PT. Akar Sari yang mengandung Alstonia cortex adalah Setianita (peluntur lemak), Paitan sari (cuci darah), Warni luntur dan Diasari (kencing manis). Kebutuhkan bahan baku pulai untuk PT ini berkisar antara $2550 \mathrm{~kg} /$ bulan dengan harga sekitar Rp. 1000/ons setara dengan Rp.10.000/kg. Selain menjual pulai dalam bentuk obat jadi, dua toko jamu milik PT Akar Sari juga menjual pulai dalam bentuk kayu kering dengan harga Rp. 1500/ons atau Rp.15.000/kg dan pulai pandak dengan harga Rp.35.000/ons setara dengan Rp. 350.000/kg (Gambar 5). PT. Akar Sari mendapatkan pasokan kulit pulai dari toko jamu grosir (Jamu Kopen) di pasar Gede, Solo.

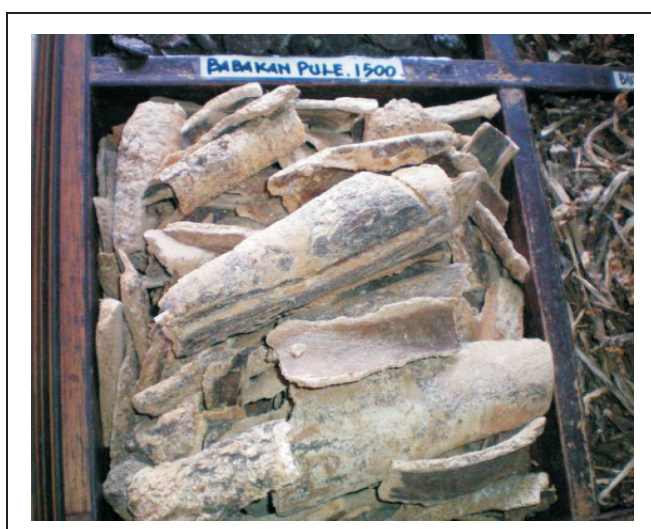

a. Pulai (Alstonia Scolaris)

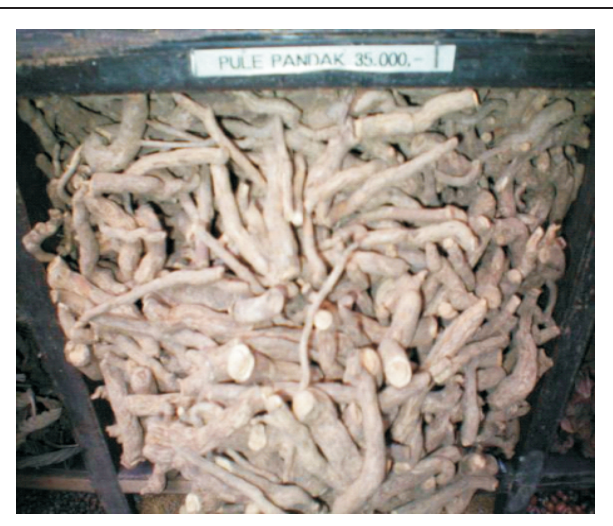

b. Pulai Pandak(Rauvolvia serpentina (L.)

Gambar 5. Kulit pulai dan pulai pandak dalam kondisi kering

Figure 5. Pulai bark and pulai pandak bark in dry conditions

PT. Air Mancur untuk memproduksi jamu hipertensi dengan nama produk Sanggageni pada awalnya menggunakan bahan baku kulit pulai, tetapi sekitar dua tahun yang lalu tidak menngunakan lagi karena ada larangan dari POM, bahwa kulit pulai bersifat toxid (kalau dosis tidak sesuai akan menyebabkan tekanan darah drop). Kulit pulai diganti dengan seledri yang mengandung apiin dan flavonoid. Volume produksi untuk jamu Sanggageni adalah sekitar 1500 bungkus per bulan dengan harga sekitar Rp. 400/ bungkus. Produk unggulan dari PT. Air Mancur adalah Madu Rasa, Harum Sari, Pegel Linu dan Sehat Perempuan. Selama ini kebutuhan bahan baku terbesar adalah empon-empon (jahe, kunyit, kencur, laos, temulawak). Suplier PT. Air Mancur berasal dari sekitar Solo (Karanganyar, Boyolali dan sekitarnya). Harapan PT. Air Mancur adalah pengembangan tanaman Purwaceng untuk kejantanan lakilaki, karena memiliki prospek pasar cerah tapi bahan baku langka.

\section{A. Prospek Pasar Pulai sebagai Bahan Baku Industri Herbal}

Prospek pasar pulai dalam penelitian ini dikaji melalui (1) seberapa besar potensi dan sebaran tanaman pulai sebagai pendekatan pasokan kulit pulai (Alstonia Cortex), karena tidak 
ada data pasokan kulit kayu pulai secara kuantitatif; (2) pemanfaatan tanaman pulai untuk melihat kegunaan dari tanaman pulai serta pemanfaatan tanaman tersebut oleh industri obat herbal; (3) tata niaga kulit kayu pulai untuk melihat ketersediaan pasar kulit kayu pulai sebagai bahan baku herbal; dan (4) permintaan kulit kayu pulai untuk obat anti hipertensi.

Selama ini industri jamu herbal tidak mengalami kesulitan dalam memperoleh bahan baku kulit kayu pulai (Alstonia Cortex). Mereka memperoleh pasokan kulit kayu pulai dari daerah Wonogiri, Lampung, Garut dan Bogor. Kenyataan ini menunjukkan bahwa pasokan kulit kayu pulai mencukupi. Apalagi jika bahan baku kulit kayu pulai ini dapat memanfaatkan sisa dari industri pensil "slate", dan industri kerajinan yang menggunakan kayu pulai.

Kulit kayu pulai juga memiliki beragam manfaat untuk mengobati berbagai penyakit, diantaranya: anti diabetes, anti diare, anti hipertensi, anti histamin, anti inflamasi, dsb. Hal ini merupakan peluang kulit kayu pulai untuk lebih banyak digunakan sebagai bahan baku obat herbal. Dari 3 perusahaan yang masih menggunakan bahan baku kulit pulai, kebutuhan bahan baku kult pulai total berkisar antara $245275 \mathrm{~kg} /$ bulan. Kebutuhan bahan baku pulai terbanyak adalah pada PT. Jamu Jago, yaitu $200 \mathrm{~kg} /$ bulan. PT. Jamu Jago dapat bertahan dalam industri jamu, terutama jamu yang berbahan baku kulit pulai karena mereka melakukan diversifikasi penyajian jamu dalam bentuk serbuk dan kapsul. Diversifikasi penyajian jamu ini dimaksudkan untuk menangkap peluang pasar dari konsumen yang lebih menyukai kepraktisan dan modern.

\section{KESIMPULAN DAN REKOMENDASI KEBIJAKAN}

\section{A. Kesimpulan}

1. Secara alami pulai (Alstonia scolaris) tersebar di seluruh nusantara. Di Jawa Tengah pulai tersebar di kawasan konservasi di Cagar Alam dan Taman Wisata Alam di Jepara, Banjarnegara, dan Cilacap. Selain itu pulai juga dikembangkan di daerah Wonogiri. Untuk Jawa Barat, pulai tersebar di daerah Taman Nasional Gunung Halimun, Ujung Kulon, Cagar Alam Gunung Jagat (Sumedang), Majalengka, Garut dan Bogor. Pulai juga sudah dibudidayakan oleh Perhutani KPH Bogor.

2. Kulit kayu pulai (Alstonia Cortex) memiliki manfaat untuk mengobati beragam penyakit, diantaranya : anti diabetes, anti diare, anti hipertensi, anti histamin/mengobati gatal-gatal, anti inflamasi/analgetik, antitusive/ekspektoransia, obat migrain, anti haemarrhoid/anti wasir, menstrual disorder, aprodisiak pria, stamina wanita dan wanita hamil.

3. Dari segi pemasaran, kulit kayu pulai melibatkan tujuh lembaga pemasaran mulai dari produsen sampai konsumen akhir dengan tiga rantai tata niaga.

4. Permintaan obat anti hipertensi dalam penelitian ini dibedakan menjadi dua, yaitu : permintaan anti hipertensi dari bahan baku kimiawi dan bahan baku herbal. Faktor yang mempengaruhi permintaan anti hipertensi dari bahan baku kimiawi adalah harga, tetapi faktor utama yang menentukan jenis obat untuk pasien adalah dokter. Jamu yang menggunakan bahan baku kulit pulai permintaan pasar mulai berkurang. Ini berkaitan dengan perubahan selera konsumen dari produk tradisional menjadi produk modern (dalam bentuk pil, bukan serbuk).

5. Prospek pulai sebagai bahan baku obat herbal cukup tinggi, apabila dilihat dari pasokan, besarnya manfaat dan ketersediaan pasar dari kulit kayu pulai. 


\section{B. Rekomendasi Kebijakan}

Pulai memiliki peluang pasar untuk dikembangkan sebagai bahan baku obat herbal, khususnya obat anti hipertensi. Untuk mengembangkan pasar pulai sebaiknya mulai dilakukan budidaya pulai (Alstonia scholaris) untuk mengantisipasi permintaan kulit pulai, disamping untuk kegunaan lain (pensil slate, kerajinan dsb). Sedangkan untuk mengembangkan pasar obat anti hipertensi berbahan baku kulit kayu pulai sebaiknya perusahaan mengembangkan diversifikasi penyajian produk dalam bentuk yang lebih modern (dalam bentuk kapsul).

\section{DAFTAR PUSTAKA}

Armilawaty, Husnul Amalia, Ridwan Amiruddin. 2007. Hipertensi dan Faktor Resikonya dalam kajian Epidemiologi. Fakultas Kesehatan Masyarakat, universitas Hasanudin, Ujung Pandang.

BKSDA Jawa Tengah. 2008. Statistik Balai KSDA Jawa Tengah. Semarang.

Buku DOA. 2008. Daftar Obat Alam (Jilid II). BPOM Jawa Tengah. Semarang.

CMPMedica. 2008. Petunjuk Konsultasi Edisi 8 tahun 2008/2009.PT. Infomaster lisensi dari CMPMedica. Jakarta.

Dalimartha. 2001. Atlas Tumbuhan Obat Indonesia.

Harini, S., Ervizal Am. Zuhud, Ellyn K. Damayanti. 2000. Kamus Penyakit dan Tumbuhan Obat Indonesia (Etnofitomedika). Pustaka Populer Obor. Bandung.

Iskandar, Y. 2007. Tanaman Obat yang Berkhasiat Sebagai Anti hipertensi. Karya Ilmiah. Fakultas Farmasi, Universitas Padjadjaran. Bandung.

Perhutani. 2009. Laporan Buku Obor Triwulan II Kesatuan Pemangku Hutan (KPH) Bogor. Bogor.

Tomek, W.E and Kenneth L. Robinson. 1990. Agricultural Product Prices, Second Edition Cornell University Press, Ithaca.

Wollenberg, E and A. S. Nawir. 1999. Estimating the Incomes of People who Depend on Forest. In Incomes from the Forest (E. Wollenberg and A. Ingles, eds.), CIFOR-IUCN, Bogor, pp. 157-187. 